\title{
LOW QUALITY WATER TREATMENT AND DESELIMATION ABASED ON SOLAR ENERGY TECHNOLOGIES.
}

\section{El Awady, M.N., ${ }^{1}$ Abd El-Salam, M.F., ${ }^{2}$ Farrag, A.E., ${ }^{3}$ Aboelghait, K.M. ${ }^{4}$ ABSTRACT}

The present study introduces an application of solar energy in water treatment and desalination for small-scale needs. A lab scale solar system is used for brackish water and agricultural drainage water treatment and desalination. agricultural drainage water passes through sand filter to solar collector, then the heated water enters to evaporating chamber maintained at low pressure. Once the hot water enters to this chamber it is evaporated and condensed to fresh water. The effect of different factors such as solar radiation, vacuum pressure, cooling water flow rate and inlet water temperature which affect on system productivity was studied. An economic analysis was conducted to estimate the cost of water production by the proposed system. The system was efficient to reduce total dissolved solid (TDS) from 1500-2400 mg/lit to less than 15 mg/lit and to reduce the Chemical Oxygen Demand (COD) from 50$90 \mathrm{mg} / \mathrm{lit}$ to less than $5 \mathrm{mg} / \mathrm{lit}$. The proposed system gives a reasonable production of fresh water up to $5 \mathrm{~L} / \mathrm{m}^{2} /$ day. The system achieved gained output ratio (GOR) 1.2 and distillation efficiency about 52\%.

Key words: Marginal quality water - solar energy - flashing process - water desalination.

\section{1- INTRODUCTION}

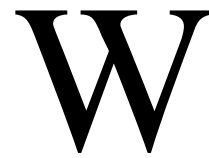
ater and energy both have a vital role in achieving the sustainable development for the countries especially in the developing countries. The total water resources available in Egypt are about 72 billion cubic meter per year (BCM/year). The withdrawal quota from the Nile River about $55.5 \mathrm{BCM} / \mathrm{year}$ represents about $76 \%$ from all water resources in Egypt, ground water extraction about $6 \mathrm{BCM} /$ year,

\footnotetext{
${ }^{1}$ Prof. Emt of Agric. Eng. Dept., Fac. of Agric., Ain shams University.

${ }^{2}$ Assist. Prof. of Agric. Eng. Dept., Fac. of Agric., Ain shams University.

${ }^{3}$ Assist. Prof. of Mech. Eng. Dept., National Research Center.

${ }^{4}$ Assist. Research of Water Pollution Dept., National Research Center.
} 
Non-conventional sources (treated wastewater and desalination) about 9 $\mathrm{BCM} / \mathrm{year}$ and rainfall which are very rare about $1.4 \mathrm{BCM} / \mathrm{year}$ (Abd ElMoniem, 2009). The utilization of agricultural drainage water (ADW) and low-quality surface water is an emerging necessity to deal with severe water shortage in arid and semi-arid land (Talaat and Ahmed, 2007). Agricultural wastewater forms the largest amount of the wastewater in Egypt. It will obviously continue to be the largest during the next decades. Agricultural drainage water (ADW) is one of the potential water resources in Egypt. The present total quantity is estimated to be $14.34 \mathrm{BCM} / \mathrm{y}$, of which about $7 \mathrm{BCM} / \mathrm{y}$ are currently used, after mixing with fresh canal water, for irrigation purposes (Abulnour et al., 2002). The most recent technologies for ADW reuse are included, desalination by membranes (Talaat et al., 2002, Lee et al., 2003) and mixing with irrigation water (Hussein et al., 2008). Omara and Eltawil, 2013 presented a solar dish concentrator (SDC) and conventional solar still (CSS) for brackish water treatment and desalination. Their results showed that the water production rate $6.71 / \mathrm{m}^{2} /$ day and $31 / \mathrm{m}^{2} /$ day with cost $.028 \$ / 1$ and $.048 \$ / 1$ for SDC and CSS respectively. Rada et al., 2013 used a solar still for sanitary and industrial wastewater treatment. Their results showed that the TDS and COD removal was $98 \%$ and $97 \%$ respectively.

In the present work, lab scale solar system based on flashing process is used for brackish and (ADW) treatment and desalination to be fit for reuse in irrigation and drinking purposes. On the other hand, this work considers reducing the cost of treatment through use of solar energy as renewable and available source of energy in arid and remote areas.

\section{2 - System description and experimental work procedure}

Fig.(1) shows the system components. ADW is filtrated by sand filter and enters to condenser at point 2 then it passes trough heat exchanger (condenser) fixed at the top of flashing chamber. Preheated water exits from the condenser at point 3 then enters to the flat plat collector (FPC) at point 4 and it exits from collector at point 5 . The heated water from FPC enters to the evaporation or flashing chamber at point 6 (maintained under vacuum). As soon as water enters to the flashing chamber, it suddenly evaporates and 


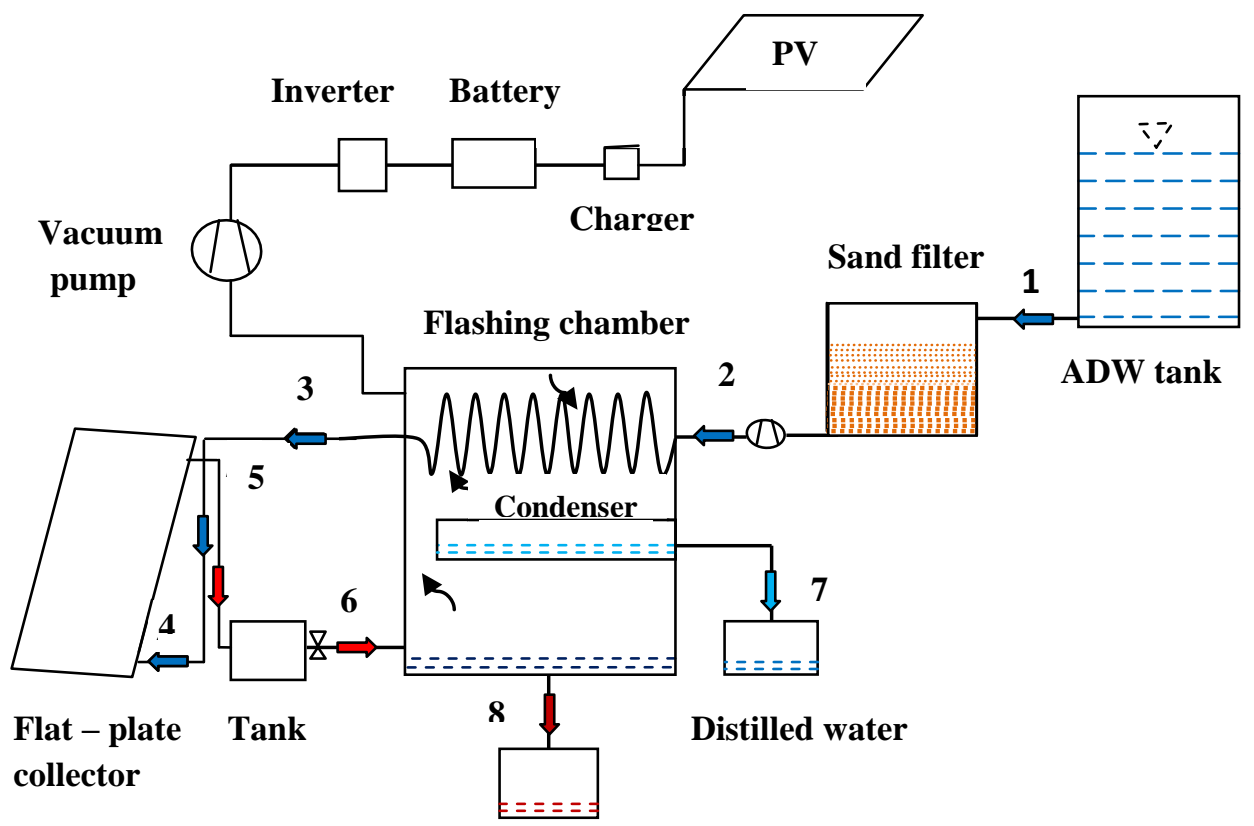

Brine

Fig. (1): Schematic diagram of the proposed system.

The proposed system of study consisted of three main stages for water treatment and desalination. A photovoltaic module (PV) to supply the system with required electricity, the main components of system as follow:

\section{2-1: Treatment and desalination stages}

\section{2-1-1: Pretreatment stage}

A sand filter was used for suspended solids removal. It comprises three sections. The bottom section consists of two layers from sand and gravel. Water is applied at the top section for filtring.

\section{2-1-2: Heating stage}

Flat-plate collector is made from galvanized steel with dimensions of $(150 \times 90 \times 15) \mathrm{cm}$. The collector has fins made of copper to increase the absorbed area of the collector. 


\section{2-1-3: Evaporating and condensing stage}

In this stage, the heated water coming from collector, is evaporated and distilled. This stage comprises the following components:

\section{2-1-3a: Evaporating chamber}

A box made from acrylic sheets (10 mm thickness) as shown in Fig.(2) cut and joined with silicon (silicon was used as adhesive material). This evaporating chamber has helical exchanger at its top use for vapor condensing. The inside acrylic box is used for distilled water collecting.

\section{2-1-3b: Heat exchanger (condenser)}

The condenser fixed at the top of flashing chamber was made from copper tubes (helically coiled). It has a length of $4 \mathrm{~m}$ and outer diameter $11 \mathrm{~mm}$ with total side area of about $1400 \mathrm{~cm}^{2}$.

\section{2-2: Solar electrical-power generation components}

The system is provided with necessary electricity to run the vacuum pump (100 watt). The following components were used:

\section{2-2-1: Photovoltaic module components}

Photovoltaic cell (polycrystalline, $150 \mathrm{Watt}, \mathrm{Vmp}=12 \mathrm{~V}$ and $\mathrm{Imp}=7.98$ Amps), charger (of $10 \mathrm{~A}$ made in Taiwan), Inverter (300 watt) and battery (100 Ah).

\section{2-2-2: Power generated by Photovoltaic module}

$\mathrm{E}_{\text {gen }}=\mathrm{P}_{\text {Peak }} \times \mathrm{PSSH} \times \mathrm{F}_{\mathrm{th}} \times \eta_{p} \times \eta_{\text {inv }}($ Ahmed and Schmid, 2002)

Where $\mathrm{P}_{\text {Peak }}$ photovoltaic module peak power, PSSH the average peak sunshine hours in Cairo $=6 \mathrm{~h}, \mathrm{~F}_{\text {th }}$ is the PV array thermal factor in Cairo, $\mathrm{F}_{\text {th }}=0.85 \eta_{P}$ battery losses and $\eta_{i n v}$ is the inverter losses.

\section{2-3 System performance evaluation}

\section{2-3-1: Gain Output Ratio(GOR) and performance ratio}

In thermal desalination processes, the (GOR) is an important parameter for the evaluation and assessment of such system. 


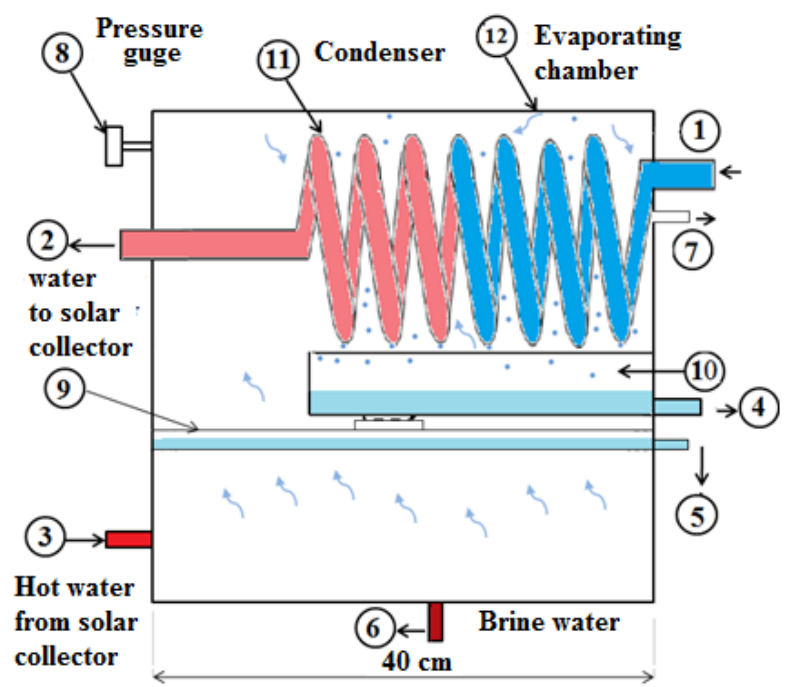

(a)

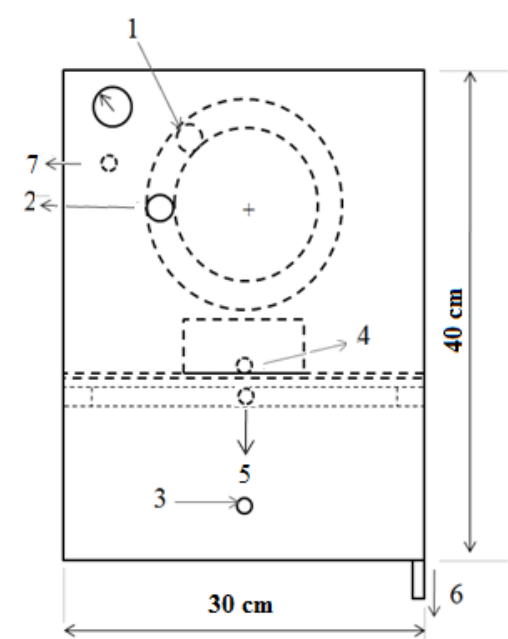

(b)

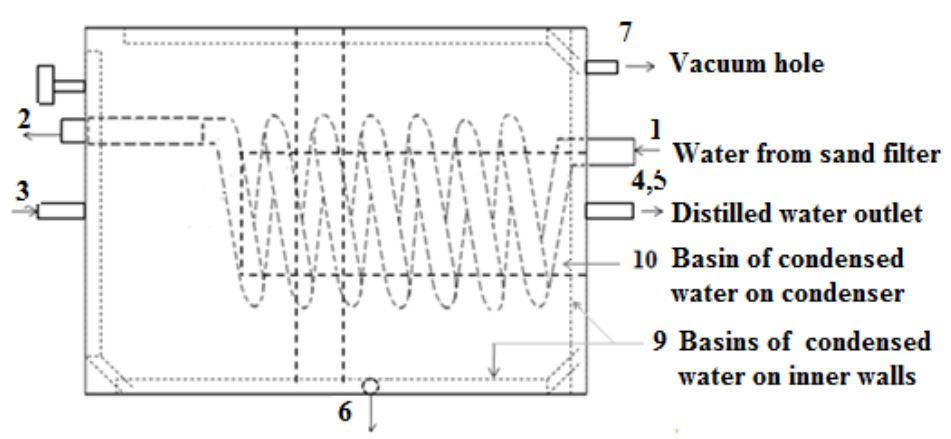

(c)

Fig. (2): Evaporating chamber components.
a) Elevation
b) Side view
c) Plan.

The GOR is a dimensionless ratio used for thermal desalination processes and can be calculated by latent heat of evaporation needed to produce the distilled water to the total input energy supplied to the system.

$$
\text { GOR }=\frac{\Delta \mathrm{h}_{\text {evap }}(\mathrm{kJ} / \mathrm{kg}) \times \dot{\mathrm{m}}_{\text {dis }}\left(\mathrm{kg} / \mathrm{m}^{2} / \text { day }\right)}{\dot{\mathrm{Q}}_{\mathrm{in}}\left(\mathrm{kJ} / \mathrm{m}^{2} / \text { day }\right)}
$$


$\Delta \mathrm{h}_{\text {evap }}$ is the latent heat of evaporation at evaporation temperature and equals $2390 \mathrm{~kJ} / \mathrm{kg}$. , $\dot{\mathrm{m}}_{\text {dis }}$ distilled water rate and $\dot{\mathrm{Q}}_{\mathrm{in}}$ is the heat added to the system.

\section{2-3-2: System efficiency}

System efficiency is the ratio of the actual distilled water obtained by the system per day to the total solar radiation received by earth in the same interval.

$\eta=\frac{W d \times \Delta h_{\text {evap }}}{G_{\text {total }} \times A_{c}} \rightarrow($ Nafey et al., 2007);

Where $\mathrm{Wd}$ is the daily produced distilled water $\mathrm{kg} / \mathrm{day}, \Delta \mathrm{h}_{\text {evap }}$ latent heat of evaporation $\mathrm{kJ} / \mathrm{kg}$., $\mathrm{G}_{\text {total }}$ total solar radiation $\mathrm{kJ} / \mathrm{m}^{2} /$ day and Ac is the collector area.

\section{2-3-3: Solar collector efficiency}

The collection efficiency of the solar heat collector indicates the ratio of the amount of the heat transferred to the water to the total amount of solar radiation received on the collector during the same period of time.

$$
\eta=\frac{m_{w} C_{p, w} \Delta T}{A \int_{\Delta t} G d t} \rightarrow \text { (Weiet al.,2013, Ma et al.,2011) }
$$

Where $\mathrm{G}$ is solar radiation in $\mathrm{W} / \mathrm{m}^{2}, \mathrm{~A}$ is collector area $\mathrm{m}^{2}, \mathrm{mw}$ is water mass in $\mathrm{kg}, \mathrm{Cp}$ is specific thermal capacity in $\mathrm{kJ} / \mathrm{kg} \cdot \circ \mathrm{C}, \Delta \mathrm{T}$ is the difference between water outlet and inlet temperatures.

\section{2-4 Economic study}

The current economic study is conducted to determine the cost of water treatment processes. The investment cost of each component constituting the system is presented in table 1 .

Many assumptions are taken into account during the study as:

- Zero Pretreatment costs (sand filter).

- Zero land cost.

- The system life expectancy is 10 years for PV module and 5 for pump and solar collector.

- Price of 1liter from distilled water was taken as 2LE. 
- The capital cost estimate for all options is based on local prices for the equipment.

- The maintenance and operating expenses are estimated at $4 \%$ of the capital cost.

- The interest rate was taken as $5 \%$.

\section{2-4-1:Cost according (Goosen et al.,2000)}

Actual annual cost (LE/year) $\mathrm{AC}=\mathrm{M}+\mathrm{AMC}-\mathrm{N}$ ( Goosen et al., 2000, Shatat et al., 2013)

$\mathrm{M}$ is the initial annual cost (LE/year), AMC is the annual maintenance cost (LE/year), and $\mathrm{N}$ is the annual salvage value (LE/year).

$\mathrm{M}=\mathrm{P} \times \mathrm{CRF}$

Where $\mathrm{P}$ is the capital cost of the system and (LE) and CRF is the capital recovery factor

$\mathrm{CRF}=\frac{\mathrm{r}(1+\mathrm{r})^{\mathrm{n}}}{(1+\mathrm{r})^{\mathrm{n}}-1}$

Where $\mathrm{r}$ is the interest rate (\%) and $\mathrm{n}$ is the life of the system (in years).

$\mathrm{N}=\mathrm{S} \times \mathrm{SFF}$

The salvage value $(\mathrm{S})$ of the system is the expected market value at the end of useful life of the system. This was considered to be $20 \%$ of the usable material cost. SFF is the sinking fund factor.

$\mathrm{SFF}=\frac{\mathrm{r}}{(1+\mathrm{r})^{\mathrm{n}}-1}$

Product $\operatorname{cost}(\mathrm{PC})=\frac{\mathrm{AC}}{\mathrm{Y}}$ Where $\mathrm{Y}$ annual yield of the system $(1 /$ year $)$.

\section{2-4-2: Cost according to (Awady, 1978)}

$\mathrm{C}=\frac{\mathrm{P}}{\mathrm{h}}\left(\frac{1}{\mathrm{e}}+\frac{\mathrm{i}}{2}+\mathrm{t}+\mathrm{r}\right)+(\mathrm{hp} \times \mathrm{S})+\left(\frac{\mathrm{W}}{144} \times 0.1\right)$

(C) Cost LE/hr, ( P) Capital investment for handling machine, (h) Yearly operating hours for handling machine, (e) Life expectancy for equipment in general, (i) Interest rate, (t) Taxes and overheads ratio, (r) 
Maintenances and repairs ratio of the total investment, (hp) Power of electric motor, (S) Power unit price, (W) Labor wage rate per month.

Table 1: Description and costs of the components of the present solar treatment system, 2013

\begin{tabular}{|l|c|c|}
\hline Components & Specification & $\begin{array}{c}\text { Total cost } \\
\text { (LE) }\end{array}$ \\
\hline Photovoltaic cell & 150 watt, $12 \mathrm{~V}$ & 1700 \\
\hline Inverter & $300 \mathrm{Watt}, 12 / 220$ Volt & 500 \\
\hline Charger & $10 \mathrm{~A}$ & 200 \\
\hline Battery & $100 \mathrm{AH}$ & 500 \\
\hline Vacuum pump & $(140 \times 80) \mathrm{watt}$ & 300 \\
\hline Solar collector & $\begin{array}{c}(1 \times 1.25) \mathrm{m}, 10 \mathrm{~mm} \\
\text { thickness }\end{array}$ & 500 \\
\hline Acrylic sheet, $\mathbf{C l e a r}$ & 200 \\
\hline Silicon rubber & $4 \mathrm{~m}, 3 / 8$ inch & 60 \\
\hline $\begin{array}{l}\text { Serpentine heat } \\
\text { exchanger copper pipe }\end{array}$ & $(1$ to -1 bar $)$ & 35 \\
\hline Pressure gauge & $\left(0^{\circ} \mathrm{C}\right.$ to $\left.350{ }^{\circ} \mathrm{C}\right)$ & 30 \\
\hline Temperature gauge & Present system & 4075 \\
\hline $\begin{array}{l}\text { Total costs of initial } \\
\text { construction }\end{array}$ & & \\
\hline
\end{tabular}

\section{3- RESULTS}

\section{3-1: water quality}

Analysis of monthly samples according to (APHA 2005) showed that agricultural drainage water characteristics are changing seasonally as related to irrigation drainage and fertilization schedules that agree with (Talaat and Ahmed, 2007). Results also showed that the treated water qualities are not affected by the influent water quality. The proposed system achieved removal efficiency of about $99 \%$ of total dissolved solids (TDS), where the proposed system is mainly based on distillation process with removal efficiency of about $95 \%$. Fig. (3) indicates the main parameter in influent and treated water after each stage. 


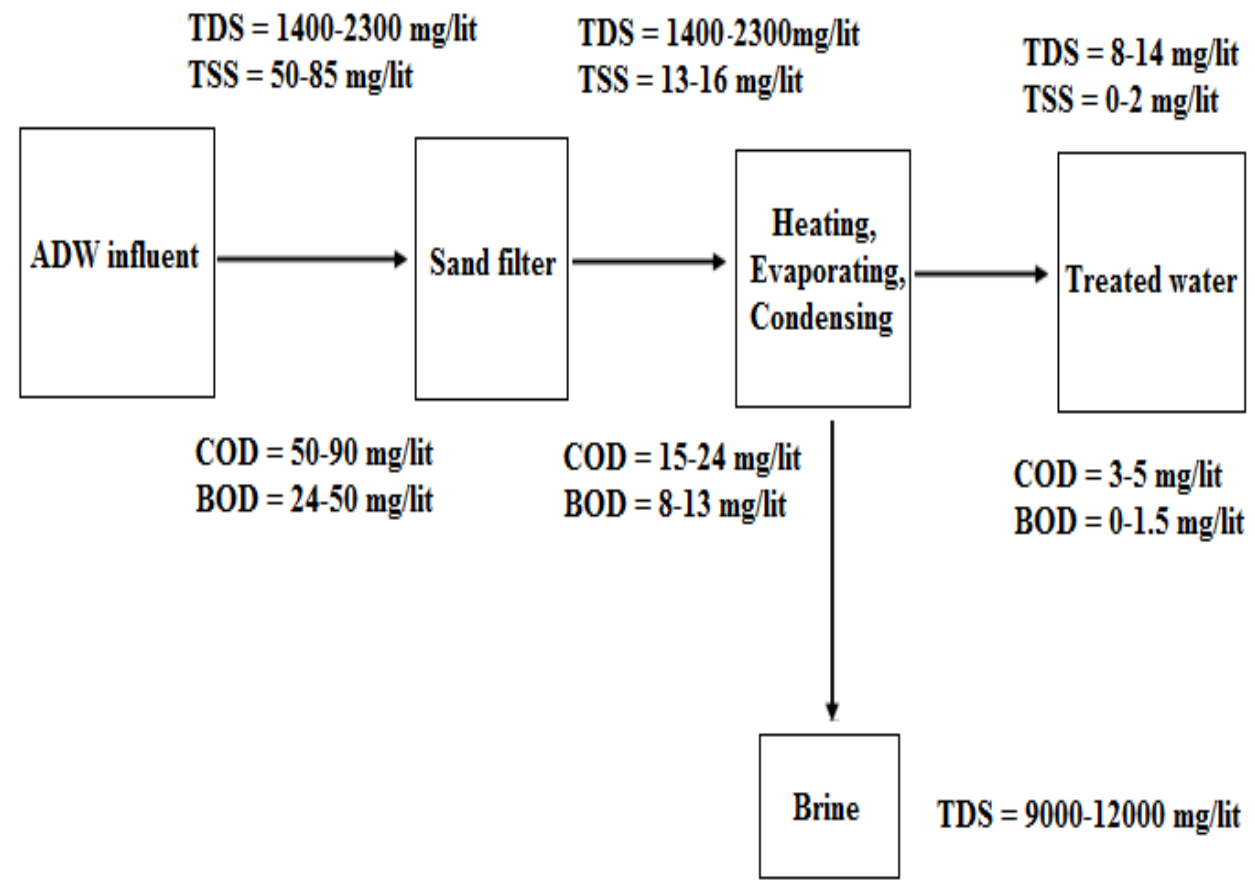

Fig. (3): System stages and water quality after each stage.

\section{3-2: Water productivity}

There are a lot of factors which have direct impacts on water productivity by the system. Such are solar radiation, pressure reduction, temperature of inlet water, water flow rate in condenser and temperature of water inlet in condenser. All of these factors were studied. They were kept constant except the factor under study which was varied.

\section{3-2a: Effect of solar radiation (G)}

The variation of solar collector productivity as a function of hourly solar radiation and system productivity with daily solar radiation is shown in Figs (4 and 5). Results showed that the increase of solar radiation increases the productivity of heated water by the solar collector. These Results are in agreement with the results of (Abdel-Rehim and Lasheen, 2007, Reddy et al., 2012, and Kabeel and Emad, (2013). They all reported that production increases with solar intensity. 


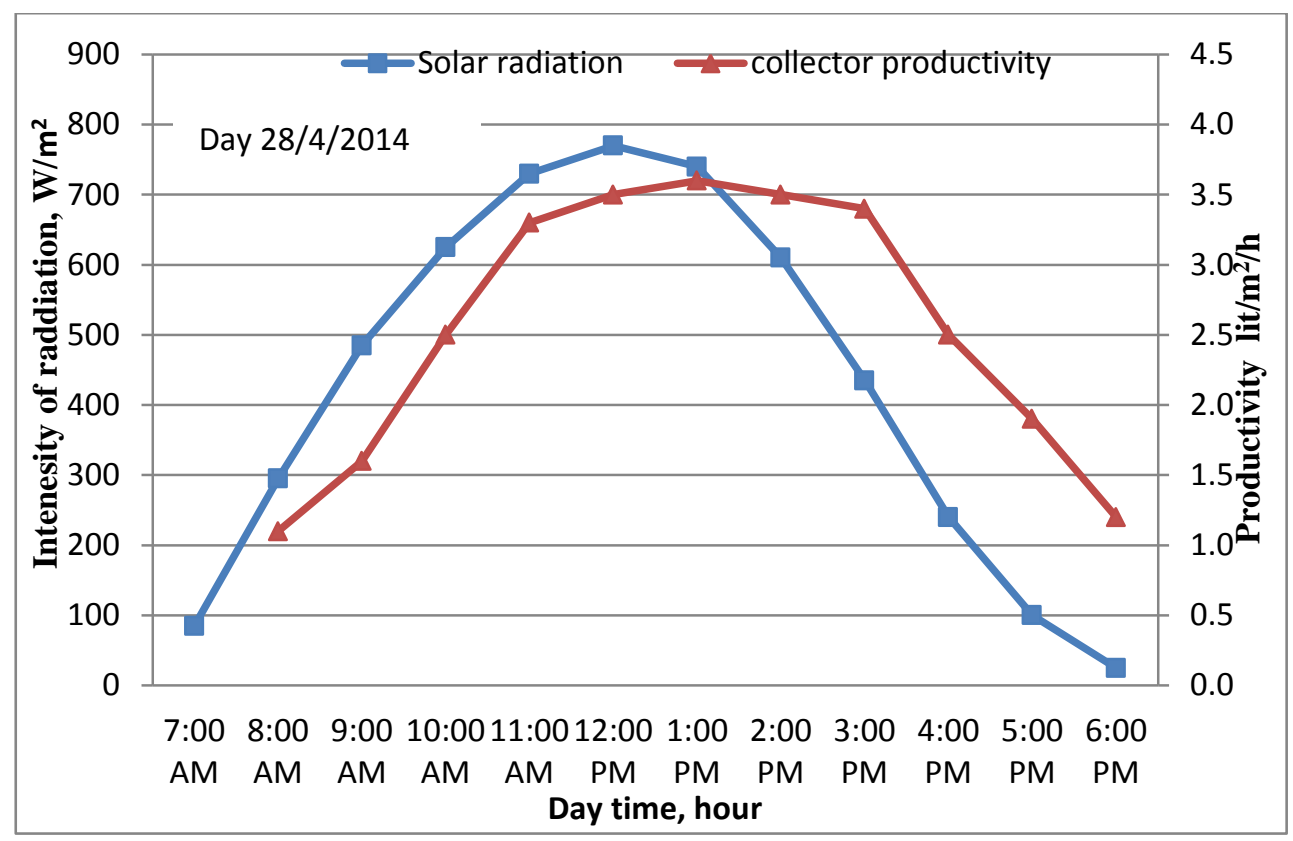

Fig.(4): Variation of solar radiation and collector productivity during the average day time.

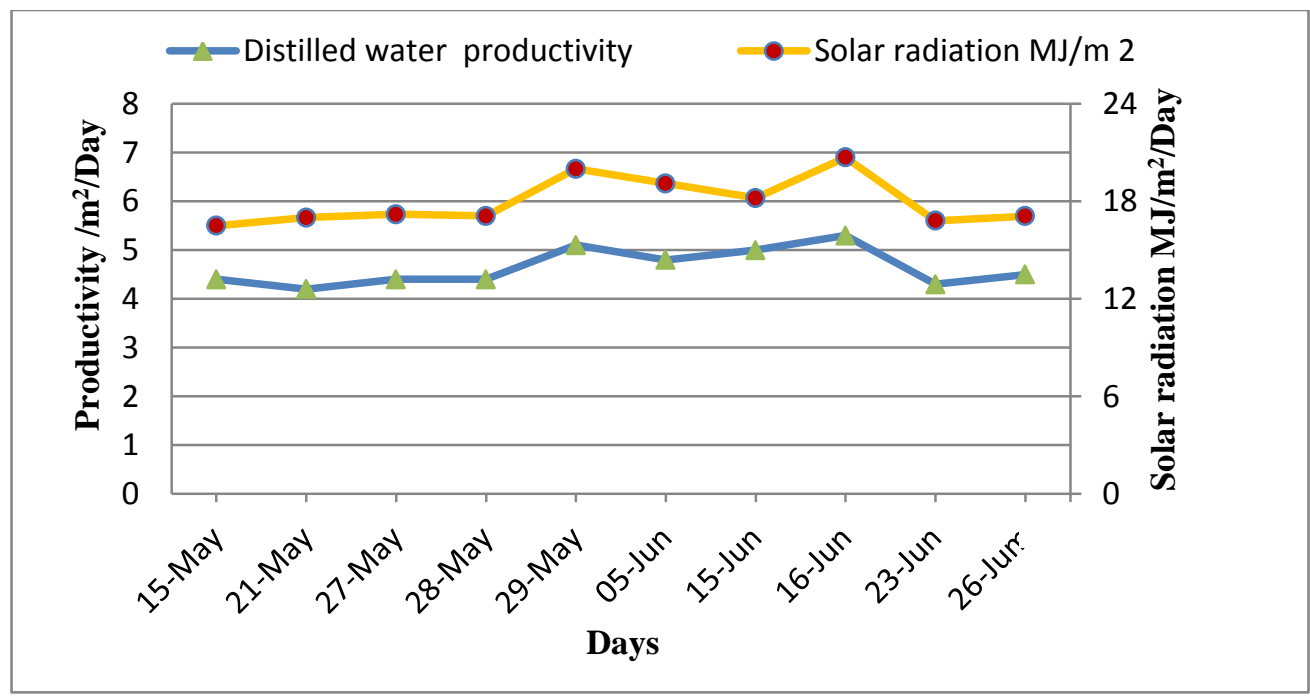

Fig. (5): Daily variation of system productivity as a function of daily solar radiation. 


\section{3-2b: Effect of pressure reduction (suction)}

Effect of pressure reduction inside the evaporating chamber at the same water inlet temperature and water inlet quantity is presented in Fig. (6). It shows that the increasing of suction (pressure reducing) leads to the increasing of distilled water because of decreasing boiling point value of water according to previous work.

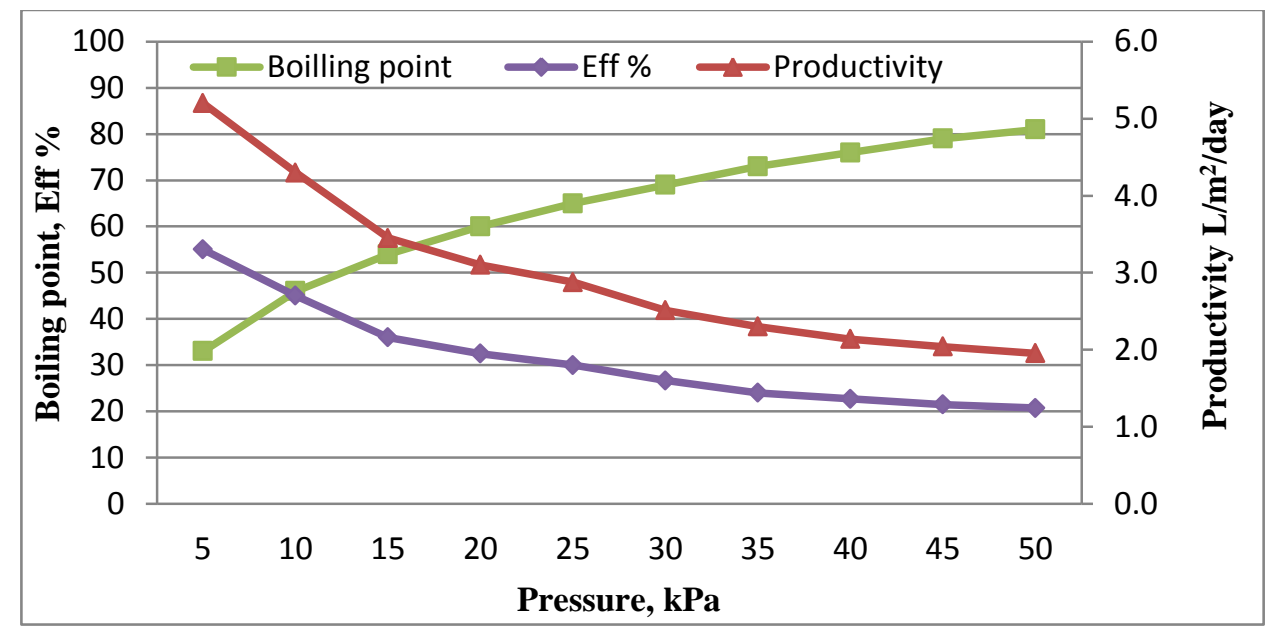

Fig. (6): Variation of system productivity as a function of pressure change.

These results are in agreement with those of (Reddy et al., 2012). They reported that distillate yield increases with decreasing pressure; due to the increase in temperature difference between the stages (they used multi stages system). It is found that the distillate yield and distillate efficiency increases from $28.04 \mathrm{~kg} / \mathrm{m}^{2} /$ day and $51 \%$ at atmospheric pressure to $53.21 \mathrm{~kg} / \mathrm{m}^{2} /$ day and $96.75 \%$ respectively at $3 \mathrm{kPa}$ pressure for fresh water.

\section{3-2c: Effect of water inlet temperature}

The water productivity is associated with the inlet water temperature at the same pressure and water inlet quantity as illustrated in Fig. (7). Results indicated that the higher water inlet temperature; the higher distilled water productivity. 


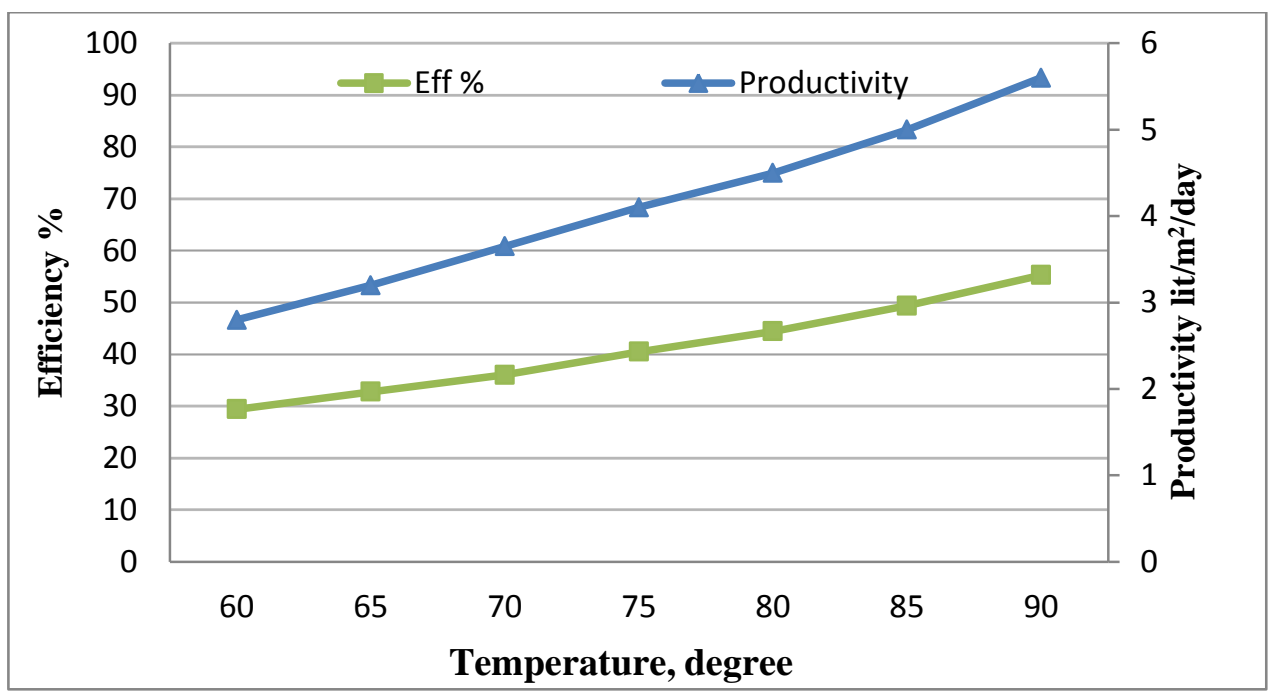

Fig. (7): Effect of feed water temperature on system productivity and efficiency.

These results are in agreement with those of (Baig et al.,2011). They reported that incrasing in inlet water temperature would increase the productivity. But on the other hand (Khawaj et al., 1997) said that high inlet water temperature would increase the potential for scale formation and accelerated corrosion of metal surfaces in contact with this water.

\section{4-2d: Effect of cooling water flow rate in the heat exchanger and inlet water temperature on the productivity}

Flow rate of cooling water in the heat exchanger (serpentine) had a significant effect on distilled water productivity, because it rejects the heat from vapor and condenses it. As shown in Fig.8, the increase in cooling water flow rate was associated with increasing of system productivity.

From the results at the same cooling water flow rate, when the temperature of inlet cooling water is reduced by 5 degrees the productivity is increased by $20 \%$. Results showed also that for each cooling water inlet temperature, there was a specific flow rate for coolant after which there was no increasing in system productivity. These results are not incomplete agreement with the results of (Kabeel et al., 2014). They reported that the impact of decreasing of cooling water inlet 
temperature has more effect on system productivity than increasing of cooling water mass flow rate.

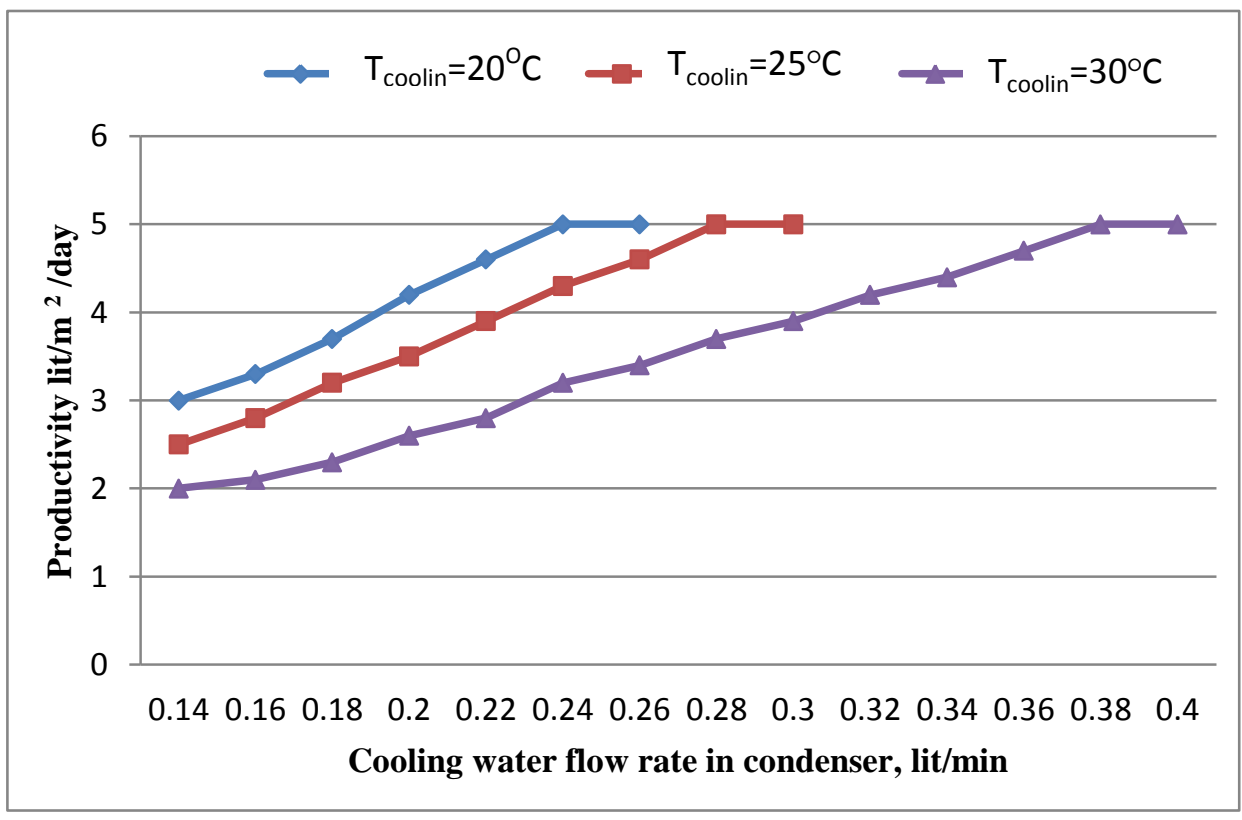

Fig. (8): System productivity change with cooling water flow rate and temperature.

\section{3-3 system performance evaluation}

The results showed that the GOR at the optimum operation conditions varied between 1.1to 1.2 and with average system efficiency (thermal efficiency) was $48 \%$ to $57 \%$. The cost of water production (according Goosen et al., 2000) 0.218LE/liter for system life time 10 year and .14 LE/liter (system life time 20 year) and according (awady, 1978) 0.40LE for system life time 10 year, but on the other hand when the cost of water productivity by this system is compared with other systems next factors should be taken into account.

- The PV module and its component form about $60 \%$ of all capital cost and it provides the system about $160 \%$ from required electricity.

- Cost of kWh produced by PV module is equal to $0.50 \mathrm{LE}$, but at present time, with electricity subsidizing from government $1 \mathrm{kWh}$ is about $0.08 \mathrm{LE}$. 
- The system life expectancy was taken as 10 years but in most references it is taken as 15-20 years.

\section{3-4: Environmental impact}

As Egypt had signed the Kyoto protocol in 1999, efforts are being made to reduce the per capita generation of carbon. The Kyoto protocol requires the global per capita emissions to drop to $0.2-0.7$ ton C/cap/yr compared with the current value of 0.3 in developing countries $(0.43$ for Egypt) ( Lamei et al., 2008). All desalination technologies are energyintensive processes that result in the emission of a huge amount of green house gases that include $\mathrm{CO}, \mathrm{CO}_{2}, \mathrm{NO}, \mathrm{NO}_{2}$, and $\mathrm{SO}_{2}$. The proposed system has no adverse environmental impacts where all the required energy for the treatment and desalination is obtained from sun (clean energy). By using conventional energy sources 1 liter from distilled water needs about $105 \mathrm{~g}$ from petrol fuel to be produce and $100 \mathrm{~g}$ from petrol fuel means about 150 to $250 \mathrm{~g}$ carbon dioxide $\left(\mathrm{Co}_{2}\right)$. Brine resulted from desalination process can be used in the solar ponds as thermal solar energy storage. On the other hand using such systems becomes mandatory for remote areas (with abundant solar energy) and acceptable source of water.

\section{4-CONCLUSION}

This research addresses the possible opportunities of recovering fresh water from brackish water and agricultural drainage water ADW using solar energy both thermal and electrical as a source of energy. The main conclusions can be summarized in the following:

- The proposed system was efficient to improve the quality of ADW where it reduced TDS from $2200 \mathrm{mg} / \mathrm{lit}$ to $8-14 \mathrm{mg} / \mathrm{lit}$, COD from $90 \mathrm{mg} / \mathrm{lit}$ to $3 \mathrm{mg} / \mathrm{lit}$. So this high quality of resulting water can be used for irrigation after mixing with untreated ADW in suitable ratio.

- The quality of treated water is independent of row water quality.

- Flashing desalination can be applied for small scale or for remote areas. 
- The estimated cost of the potable water produced is about 0.14 LE/lit and $0.21 \mathrm{LE} / \mathrm{l}$ for system life time 20 and 10 year respectively with productivity about $5 \mathrm{lit} / \mathrm{m} 2 /$ day.

- The Gained Output Ratio (GOR) of the proposed system was about 1.2 and distillation efficiency was $52 \%$.

- The productivity of the system increased with the increase of solar radiation, pressure reduction, water inlet temperature, and cooling water flow rate.

- The productivity of the system decreased with the increase of cooling water temperature.

- The solar fraction (energy supplied by solar / total energy consumed by the system) of the proposed system was about $100 \%$.

\section{5- REFERENCES}

Abd ElMoniem, A. A.,(2009). Overview of Water Resources and Requirements in Egypt; The Factors Controlling its Management and Development. Journal of Environmental Studies, 2:85-97

Abdalrehim, Z. S. and Lashin, A. (2007), Experimental and theoretical study of a solar desalination system located in Cairo, Egypt. Desalination; 217:52-64.

Ahmad. G.E. Schmid J. (2002). Feasibility study of brackish water desalination in the Egyptian deserts and rural regions using PV systems. Energy Conversion and Management, 43 : 2641-2649.

Abulnour,A.G; Sorour.M.H ; Talaat, H.A.(2002). Comparative economics for desalting of agricultural drainage water (ADW). Desalination, 152: 353-357.

APHA, American Public Health Association,(2005). Standared methods for the examination of water and wastewater, 21 th ed. United Book press, USA

Awady, M. N., (1978). Tractor and Farm Machinery. Text(Arabic)., Col. Ag., Ain Shams U. : 146 - 167. 
Baig, H. Antar, M.A. Syed, M. Zubair,S.M.(2011). Performance evaluation of a once-through multi-stage flash distillation system: Impact of brine heater fouling. Energy Conversion and Management, $52: 1414-1425$.

Goosen, F.A. Sablani S. S. Shayya, W. H. Charles, P.Hilal, A.(2000). Thermodynamic and economic considerations in solar desalination. Desalination, 129: 63-89.

Hussein, A.A. ElGamal;Hatem, M.M.Ali.(2008).Commissioning of bandoned drainage water reuse systems in Egypt: A case study of upgrading the umoum project, Nile delta.The3rd international conference on water resources and arid environments and the 1st Arab water forum.

Kabeel, A.E. Emad, M.S.(2013). A hybrid solar desalination system of air humidification-dehumidification and water flashing evaporation Part I. A numerical investigation. Desalination, 320: 56-72

Kabeel, A.E. Emad, M.S.(2014). Applicability of flashing desalination technique for small scale needs using a novel integrated system coupled with nano fluid-based solar collector. Desalination, 333 : $10-22$

Khawaji, A.D. Wie, J. and Khan, T.(1997) Proc., IDA World Congress on Desalination and Water Reuse, Madrid, Spain, Oct. 6-9, 1997, 2 (1997) 3.

Koschikowski, J.Wieghaus,M.Rommel,M.(2003). Solar Thermal-Driven desalination Plants Based on Membrane Distillation .Desalination, 156:295-304

Lamei, A. van der Zaag, P. von Munch, E.(2008). Impact of solar energy cost on water production cost of seawater desalination plants in Egypt. Energy Policy, 36 : 1748-1756 
Lee,R.W;Glater,j;Cohen,y;Martin,C;Kovac,K;Milbar,M.N;Bartel,D.W (2003) Low-pressure RO membrane desalination of agricultural drainage water. Desalination, 155:109-120

Ma, J. Sun, W. Ji, J. Zhang, Y. Zhang, A. Fan, W.(2011). Experimental and theoretical study of the efficiency of a dual-function solar collector. Applied Thermal Engineering, 31: 1751-1756

Nafey, A. Safwat. Mohamad, M.A. El-Helaby, S.O. Sharaf, M.A.(2007). Theoretical and experimental study of a small unit for solar desalination using flashing process Energy Conversion and Management, 48: 528-538.

Omara, Z.M., Eltawil, M. A.(2013). Hybrid of solar dish concentrator, new boiler and simple solar collector for brackish water desalination. Desalination, 326:62-68.

Rada, Z. A, Fatihah, S, Mohd, H. R, Nurul'ain, A.(2013). The application of a solar still in domestic and industrial wastewater treatment. Solar Energy; 93:63-71.

Reddy, K.S. Kumar, K. R. O'Donovan, T. S. Mallick, T.K.(2012). Performance analysis of an evacuated multi-stage solar water desalination system Desalination, $288: 80-92$.

Shatat,M. Worall,M. Riffat, S.(2013). Economic study for anaffordable small scale solar water desalination system in remote and semi-arid region. Renewable and Sustainable Energy Reviews, 25:543-551.

Talaat, H.A; Sorour.M.H ; Rahman.N.A;Shaalan H.F.(2002). Pretreatment of agricultural drainage water (ADW) for large-scale desalination. Desalination, 152: 299- 305.

Talaat, H.A;Ahmed.S.R.(2007).Treatment of agricultural drainage water: technological schemes and financial indicators. desalination, 204:102-112. 
Wei, L. Yuan, D. Tang, D. Wu, B.(2013). A study on a flat-plate type of solar heat collector with an integrated heat pipe. Solar Energy, 97: $19-25$.

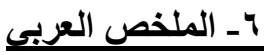

\section{معالجة وتحلية المياه محدودة الجودة إعتمادا على تقنيات الطاقة الثمسية}

\section{محمد نبيل العوضي' مصطقي فهيم عبدالسلام" احمد الفاتح فراج" كريم محمد ابوالغيط؛}

أصبح إستخدام المصادر غير التقليديه للمياه ضرورة ملحة في الوقت الراهن للمواجهه العجز

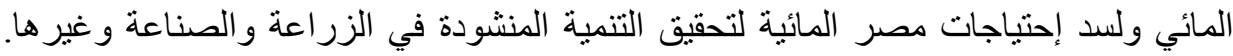

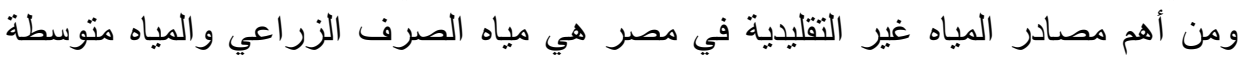

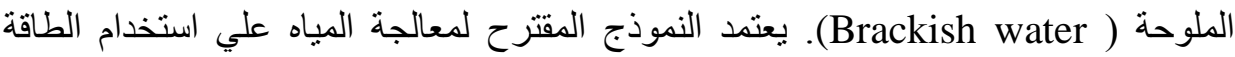

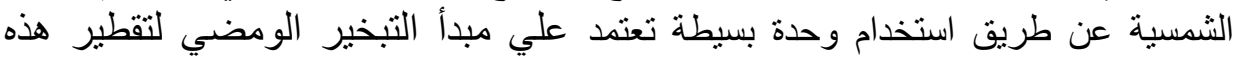

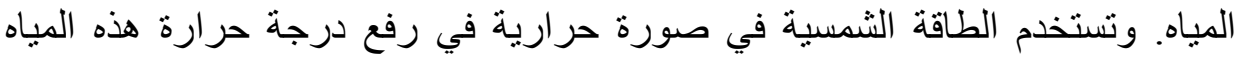

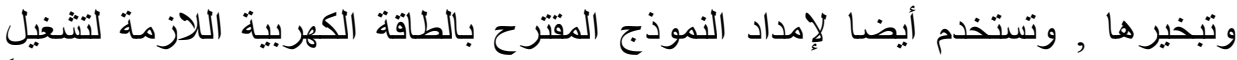

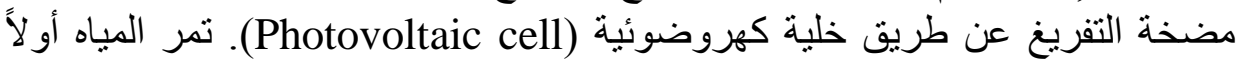

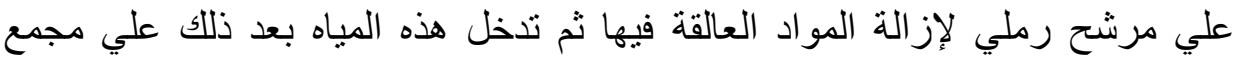

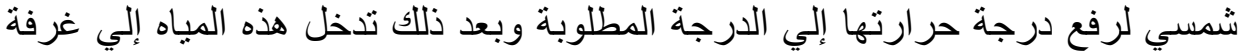

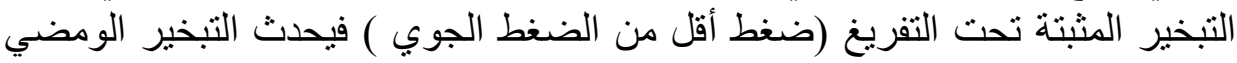

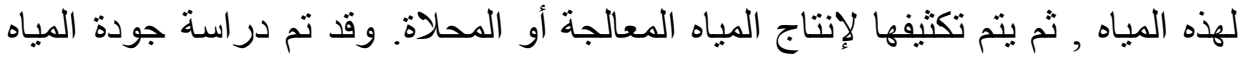

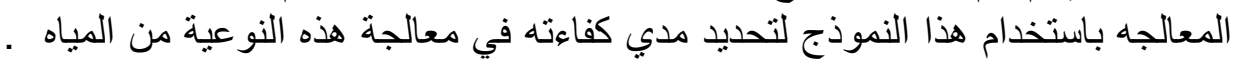

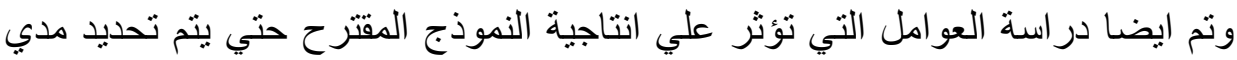

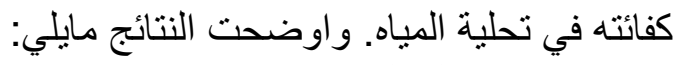
يمكن تحقيق إز الة للمو اد العضوية بنسبة جو و 9 \% وكذلك إز الة الأملاح الموجودة في هذه

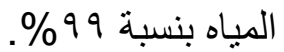

النموذج المقترح يمكنه انتاج ه لترمن المياه المحلاه/ لكل متر مربع/ يوم من مساحة

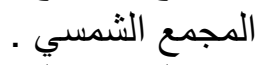
حقق النموذج المقترح كفاءة حرارية بمنوسط ror\% وكذللك معامل استفادة (GOR)

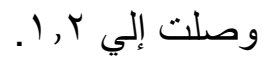
النموذج المقترح ليس له اي اثار جانبية علي البيئة حيث أن الطاقة المستخدمة يتم

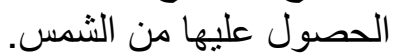

\footnotetext{
'أستاذ متفرغ - قسم الهندسة الزراعيةـ كلية الزر اعةـ جامعة عين شمس.

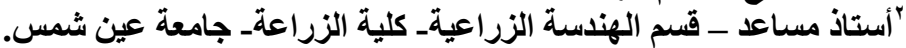

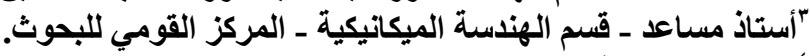

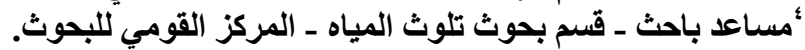

